\title{
Correlation of Femoral Cartilage Thickness and Osteoporosis in Female Patients with Knee Osteoarthritis
}

\author{
Diz Osteoartritli Hastalarda Femoral Kıkırdak Kalınlığı ve Osteoporoz Ilişkisi \\ (1) Gamze Altuğ Özövez, (1) Alev Alp
}

Bursa Uludağ University Faculty of Medicine, Department of Physical Medicine and Rehabilitation, Bursa, Turkey

\section{Abstract}

Objective: To evaluate the relationship between ultrasonographic femoral cartilage thickness and presence of concomitant osteoporosis in a group of female patients with knee osteoarthritis (OA).

Materials and Methods: This study included 118 women with knee OA who visited our outpatient clinic. Demographic data were collected, radiologic grading using Kellgren Lawrence (K-L) scale, ultrasonographic femoral cartilage thickness (FCT) evaluation, pain intensity evaluation, disability evaluation using OA index [Western Ontario and McMaster Universities Osteoarthritis index (WOMAC)], quality of life measurement using Short Form-36 (SF-36) and bone density measurement using dual-energy X-ray absorptiometry (DXA) were conducted for each patient. Results: We found that 58 patients (median age: 64.5 years, range: 50-75) had osteoporosis (group 1) and 60 patients (median age: 62 years, range: 51-75) did not have osteporosis (group 2). Group 2 had higher body mass index (BMI) in addition to lower WOMAC, SF-36 physical function, physical role limitation, pain and social function scores. The severity of osteoporosis and K-L staging were negatively correlated. The DXA femoral neck and total lumbar T-scores were higher in the advanced stages of OA. FCT had no significant correlation with age, WOMAC index and SF-36 scores. Moreover, the left knee FCT was negatively correlated with BMI.

Conclusion: Radiologic staging of OA had a negative correlation with osteoporosis but no significant correlation with the quantitative measurement of FCT using ultrasonography.

Keywords: Femoral cartilage thickness, knee osteoarthritis, osteoporosis, ultrasonography, SF-36, WOMAC

\section{Öz}

Amaç: Diz osteoartriti (OA) olan kadın hastalarda ultrasonografik femoral kıkırdak kalınlığı ve eş zamanlı osteoporoz varlığı arasında ilişki olup olmadığının araştırılmasıdır.

Gereç ve Yöntem: Çalışmaya, polikliniğe başvuran ve her iki dizinde OA bulunan 118 kadın hasta dahil edildi. Hastaların demografik verileri, radyolojik Kellgren Lawrence (K-L) evreleme, ultrasonografi ile femoral kıkırdak kalınlığı (FKK) ölçümü yapıldı. Numerik ağrı değerlendirmesi, OA indeksi [Western Ontario ve McMaster Universitesi Osteoartrit indeksi (WOMAC)], genel sağlık ölçütü ve yaşam kalitesi değerlendirmesi Kısa Form-36 (SF-36) ve kemik mineral yoğunluğu için çift enerjili X-ışını absorbsiyometrisi (DXA) yapılarak kaydedildi.

Bulgular: Yaş ortalaması 64,5 (aralık: 50-75) olan 58 hastada osteoporoz mevcut iken (grup 1), yaş ortalaması 62 (aralık: $51-75)$ olan 60 hastada osteoporoz yoktu (grup 2). Grup 2'de vücut kitle indeksi (VKi) daha yüksek bulundu. K-L evreleme arttıkça osteoporoz insidansı azalma eğilimindeydi. İleri evre OA'da DXA femur boyun, lomber total T-skor ölçümleri yüksek saptandı. Osteoporoz olmayan grupta istatistiksel olarak WOMAC ağrı, tutukluk, fonksiyon ve total skorları daha yüksek, SF-36 fiziksel fonksiyon, fiziksel rol kısıtlanması, ağrı, sosyal fonksiyon skorları daha düşük saptandı. Osteoporoz varlığı ve K-L evreleme ile FKK ölçümü arasında anlamlı ilişki saptanmadı. Sol diz FKK VKi ile negatif korelasyon göstermekteydi.

Sonuç: Radyolojik OA ve osteoporoz arasında negatif ilişki saptanmıştır. Ultrasonla FKK ölçümü ve diz OA derecesi arasında anlamlı bir ilişki gözlenmemiştir.

Anahtar kelimeler: Femoral kıkırdak kalınlığı, diz osteoartriti, osteoporoz, ultrasonografi, SF-36, WOMAC

Address for Correspondence/Yazışma Adresi: Alev Alp Prof. MD, Bursa Uludağ University Faculty of Medicine, Department of Physical Medicine and Rehabilitation, Bursa, Turkey

Phone: +90 2242347691 E-mail: dr.alevalp@gmail.com ORCID ID: orcid.org/0000-0002-3904-5463

Received/Geliş Tarihi: 23.09.2020 Accepted/Kabul Tarihi: 09.11.2020

${ }^{\circ}$ Copyright 2021 by the Turkish Osteoporosis Society / Turkish Journal of Osteoporosis published by Galenos Publishing House. 


\section{Introduction}

Osteoarthritis (OA) is a major cause of disability and is among the most frequent forms of musculoskeletal disorders. It is characterized pathologically with both focal loss of articular cartilage and marginal and central new bone formation. The knee particularly is assumed to be an important healthcare problem associated with symptoms of pain and functional disability (1).

Osteoporosis is called the "silent thief" because it steals bone without immediate consequence or attention, and it results in low bone mass and the structural deterioration of bone, ultimately leading to fragility fractures. Fractures of the spine and hip are known to be the major determinants affecting quality of life in elderly people. Antiresorptive (bisphosphanates and denosumab) and anabolic (parathormone, growth hormone) medications have been developed to prevent and treat those people at risk (2).

Though relationship between osteoporosis and OA is presumed to be completely controversial with differences in risk factors; bone mineral density (BMD), body mass index (BMI), phenotype, morbidity and mortality, they share some epidemiological profiles and in both diseases bone metabolism plays a crucial role in the pathophysiology. Several recent reviews have summarized the extensive literature on cross-sectional and prospective cohort and population-based studies that discuss the relation between $\mathrm{OA}$ and osteoporosis. This relation is complex, in terms of BMI, $\mathrm{BMD}$, bone loss, subchondral bone changes, genetic background, fracture risk and the role of mechanical and systemic factors. Furthermore, in the literature, there is considerable heterogeneity in the way OA is defined. OA is a heterogeneous disease in terms of staging (early versus late), location (weight-bearing versus nonweight-bearing and monoarticular versus polyarticular), definition (clinical and radiographic), classification (according to concomitant inflammation or sequential involvement of cartilage, bone and connective tissue), risk factors (local or systemic) and methods of imaging [radiography, magnetic resonance imaging (MRI), ultrasonography (USG)] (3).

In the Framingham study, it was found that femoral BMD was higher in those with osteophytosis of the knee, and that BMD is not necessarily associated with joint space narrowing among women (4). In the Rotterdam study, radiographic OA was associated with high BMD and also increased rate of bone loss (5). Both of these studies have the largest sample sizes with 1,154 and 2,745 patients respectively. There are some other studies with conflicting results (6-8).

This cross-sectional study observes the relationship between radiologic or ultrasonographic knee OA and osteoporosis of the lumbar and femoral regions. Concurrently, the correlation of ultrasonographic evaluation with demographic factors and disability is also investigated.

\section{Materials and Methods}

In this cross-sectional population based study, 118 female patients were included with knee OA according to 1986 ACR criteria who attended to our outpatient clinic (9). Demographic data as age, menopause status, current osteoporosis treatment and BMls $\left(\mathrm{kg} / \mathrm{m}^{2}\right)$ were checked. Radiologic staging of knee OA by Kellgren Lawrence (K-L) (10), ultrasonographic femoral cartilage thickness (FCT) by $11-\mathrm{MHz}$ lineer transduser (GE Healthcare, Logiq P5), pain intensity evaluation by numeric pain scale (NPS) (11), disability evaluation by osteoarthritis index [Western Ontario and McMaster Universities Osteoarthritis index (WOMAC)] (12), quality of life measurement by Short Form-36 (SF-36) $(13,14)$ and BMD measurement by dual-energy X-ray absorptiometry (DXA) (15) were done for each patient. The patients were seperated into 2 groups with (G1) or without osteoporosis (G2).

Inclusion criteria were to be female, ages between 50-75 and OA staging of K-L between 1 to 3 for knee OA. Exclusion criteria were; to be K-L staging 4 , to have had a surgical procedure, concomittant inflammatory arthritis, plegia or neuropathic disorders and using glucosamine/chondroitin sulfate supplements. Uludağ University Clinical Research Ethics Committee approval was obtained for the study with the number of 2016-7/13 (date: 12.04.2016). All subjects who met the study criteria were informed of the nature of the study and a written consent was obtained.

Ultrasonographic evaluation was done by ultrasound while the patient lied in supine position with her knees in maximum flexion. The ultrasound probe was placed on the suprapateller region in axial plan in order to view the unechoic femoral cartilage between the cortex and the suprapatellar fat. The FCT was measured at medial, intercondylar and lateral regions to calculate the average thickness (Figure 1).

DXA measurements were done by Hologic Horizon Wi S/N 201290 at the university hospital radiology unit. T-scores below -2.5 for lumber total, femur neck (FN) and femur total (FT) BMDs were accepted as osteoporosis referring to World Health Organization classification criteria. The BMD value of the discrete/crushed vertebrae corpus was subtracted from the value of total lumbar BMD for not causing a wrong decision (Figure 2).

NPS is a one-dimensional 11-point numeric scale ranges from ' 0 ' representing 'no pain' to '10' representing the pain' as bad as you can imagine'. For construct validity, the NPS was shown to be highly correlated with the visual analogue scale in patients with rheumatic and other chronic pain conditions; correlations range from 0.86 to 0.95 .

WOMAC is a disability scale for OA containing 3 parts; pain (5 questions), stiffness (2 questions) and physical function (17 questions) in which Likert scale between 0-4 is used for evaluation. The scores increse as the symptoms get worse. Validity and reliability study for Turkish version of WOMAC was published previously (12).

SF-36 is a measurement tool for quality of life containing totaly 36 questions in 8 divisions; physical functioning, physical role limitation, emotional role limitation, bodily pain, social functioning, mental health, vitality and general health. Scores 
are between 0-100 while high scores match with better health status. Validity and reliability study for Turkish version of SF-36 was published previously $(13,14)$.

\section{Statistical Analysis}

The statistical analyses were done with SPSS version 21.0. Shapiro-Wilk test was used to test the normality of variables. Descriptive statistics were explained as mean \pm standard deviation or median (maximum-minimum) for normal distribution or not respectively. Pearson's chi-squared and Yates corrected chi-squared tests were used for descriptive statistics for cathegorical data of independent groups. One-Way ANOVA was used for double comparison of multivariate data. KruskalWallis test was used for the comparison of multivariate data which were not normally distributed. Correlations between the normally distributed variables were calculated by Pearson correlation test. Spearman correlation test was used for the variables which were not normally distributed. The level of significance for all tests was taken as $\alpha=0.05$.
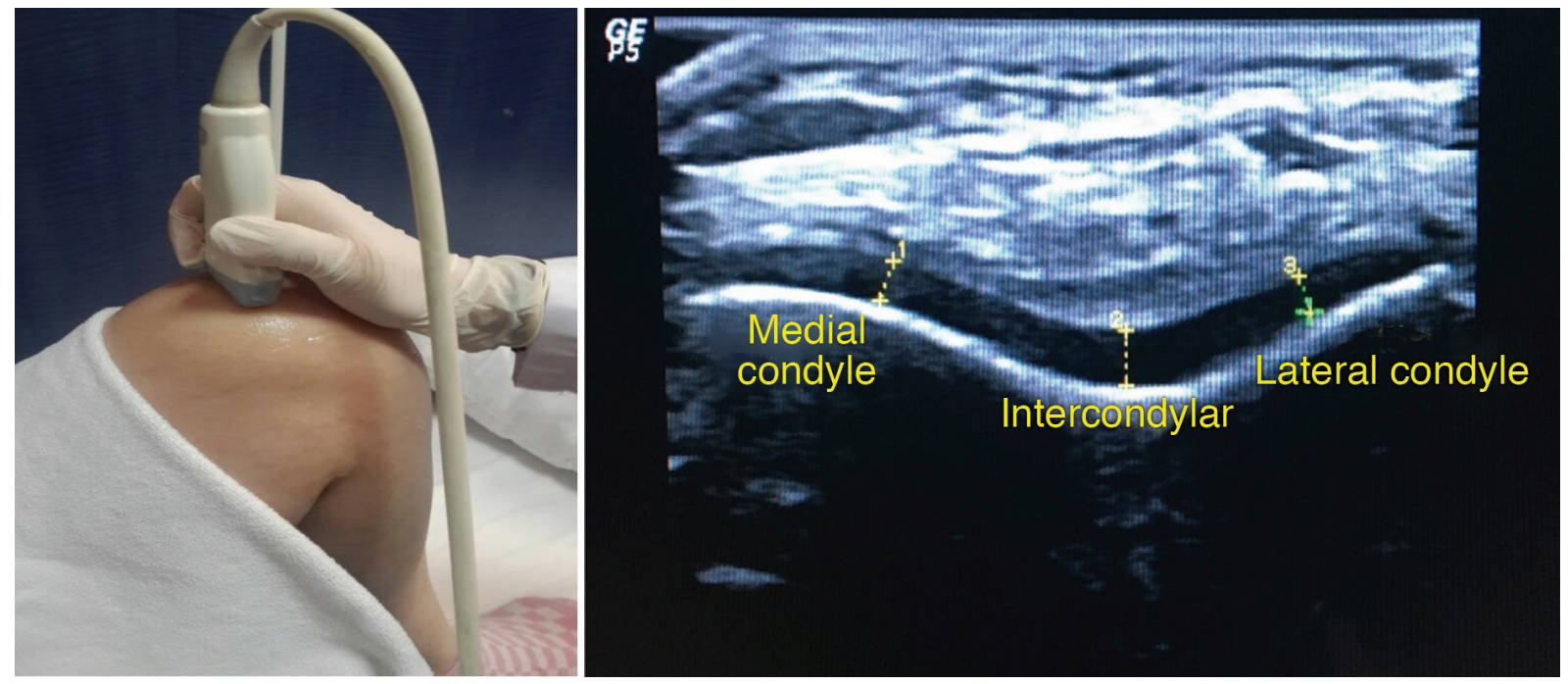

Figure 1. Positioning the ultrasonographic probe in axial plan and imaging the cartilage in 3 points

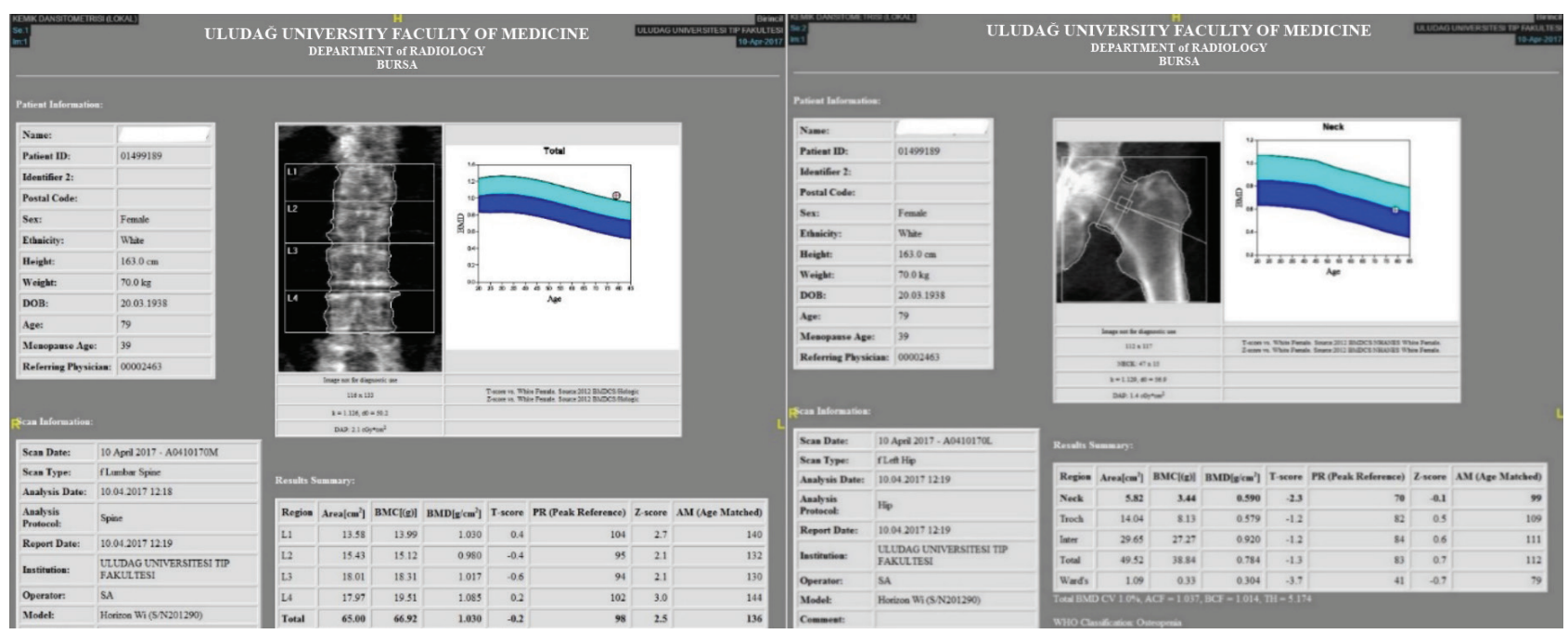

Figure 2. Bone mineral density and T-score measurement by dual-energy X-ray absorptiometry 
the knees were in reverse relationship with osteoporosis according to T-scores. Osteoporosis decreased as the K-L stage increased. Femoral neck and lumbar total T-scores of BMD measurements were higher in the advanced stages of $\mathrm{OA}$ at both right and left knees ( $p=0.015$ for FN and $p=0.003$ for LT T-scores of right knee, $p=0.045$ and $p=0.012$ for FN and LT T-scores of left knee). BMI had positive correlation with radiologic K-L grading $(p<0.001)$. (Table 2).

In double comparisons of the variables; the right knees having grade 3 OA had higher FN T-scores when compared to knees with grade $2 \mathrm{OA}(p=0.014)$. Similarly knees with grade $3 \mathrm{OA}$ had better LT T-scores when compared to knees with grade 1 and $2 \mathrm{OA}(p=0.05)$. In the left knees; patients with grade $3 \mathrm{OA}$ had higher FN T-scores when compared to patients with grade $1 \mathrm{OA}$ $(p=0.041)$. Invariably grade 3 OA had higher LT T-scores when compared to grade $1 \mathrm{OA}(\mathrm{p}=0.003)$. Other double comparisons were statistically insignificant.

The correlation of FCT with demographic data, disability and general health variables put forth only BMI for consideration which was negatively correlated to FCT at the left knee ( $p=0.041$, $r=-0.189$ ) (Table 3).

\section{Discussion}

In this cross-sectional observational study we determined that 1) knee OA patients without osteoporosis had worse scores in quality of life and disability when compared to the group of patients with osteoporosis in which higher BMI maybe the key factor, 2) there was a negative relationship between osteoporosis intensity and K-L staging of OA, 3) there was no significant correlation between FCT of the osteoarthritic knees and any other variables except BMI. 4) High BMI was in negative corelation with osteoporosis and FCT of the left knee.

The population-based Chingford study revealed the positive correlation between generalised OA and BMD in 1994 (16). In the Framingham study it was found that femoral BMD was higher in the group of female patients with knee OA with osteophytosis when compared to the group without

Table 1. Demographic variables and basic evaluations of the patients with knee OA according to the existence of concomittant osteoporosis

\begin{tabular}{|c|c|c|c|}
\hline & $\begin{array}{l}\text { Group } 1 \\
\text { with OP }(n=58) \\
\text { Median }(\text { min-max }) / \text { mean } \pm \text { SD }\end{array}$ & $\begin{array}{l}\text { Group } 2 \\
\text { without OP }(n=60) \\
\text { Median }(\text { min-max }) / \text { mean } \pm \text { SD }\end{array}$ & p \\
\hline Age & $64.5(50-75)$ & $62(51-75)$ & 0.516 \\
\hline Menopause age & $46.67 \pm 5.42$ & $45.53 \pm 6.00$ & 0.282 \\
\hline $\mathrm{BMI}\left(\mathrm{kg} / \mathrm{m}^{2}\right)$ & $27.51(20-40)$ & $31.22(23-42)$ & 0.000 \\
\hline Right knee medial FCT (mm) & $1.46 \pm 0.50$ & $1.39 \pm 0.39$ & 0.421 \\
\hline Right knee intercondylar FCT (mm) & $1.60(0.33-2.99)$ & $1.73(0.89-3.70)$ & 0.228 \\
\hline Right knee lateral FCT (mm) & $1.56(0.22-2.74)$ & $1.56(0.80-2.92)$ & 0.454 \\
\hline Right knee average FCT (mm) & $1.54 \pm 0.44$ & $1.61 \pm 0.38$ & 0.370 \\
\hline Left knee medial FCT (mm) & $1.44 \pm 0.49$ & $1.40 \pm 0.35$ & 0.667 \\
\hline Left knee intercondylar FCT (mm) & $1.73 \pm 0.51$ & $1.73 \pm 0.41$ & 0.874 \\
\hline Left knee lateral FCT (mm) & $1.39 \pm 0.44$ & $1.47 \pm 0.42$ & 0.319 \\
\hline Left knee average FCT (mm) & $1.52 \pm 0.39$ & $1.53 \pm 0.30$ & 0.849 \\
\hline WOMAC-pain & $2(0-8)$ & $3.5(0.5-7.5)$ & 0.003 \\
\hline WOMAC-stiffness & $2.5(0-10)$ & $3.75(0-10)$ & 0.019 \\
\hline WOMAC-function & $2.13(0-6.91)$ & $3.45(0.44-6.91)$ & 0.000 \\
\hline WOMAC-total & $6.35(0.5-23.38)$ & $10.49(0.94-22.37)$ & 0.001 \\
\hline SF-36 physical function & $55.0(10-100)$ & $42.5(0-95)$ & 0.008 \\
\hline SF-36 physical role limitation & $100(0-100)$ & $0(0-100)$ & 0.017 \\
\hline SF-36 pain & $51.0(22-100)$ & $41.0(2-84)$ & 0.006 \\
\hline SF-36 general health & $61.0(15-82)$ & $60(5-86)$ & 0.326 \\
\hline SF-36 energy & $45.0(0-95)$ & $40.0(0-90)$ & 0.320 \\
\hline SF-36 social function & $87(25-100)$ & $68.5(25-100)$ & 0.040 \\
\hline SF-36 emotional role limitation & $100(0-100)$ & $100(0-100)$ & 0.191 \\
\hline SF-36 mental health & $72.0(20-180)$ & $60.0(14-100)$ & 0.710 \\
\hline
\end{tabular}


osteophytosis (4). In 2 of the osteoporotic fracture studies it was found that patients with coxarthrosis had higher BMD but fracture risk has remained the same $(17,18)$. This last result was also supported by Rotterdam study in which it was come to a conclusion that vertebral and nonvertebral fracture risk was higher in the patients with knee OA, independent of the $\mathrm{BMD}$ variables (5). High BMI, genetic factors, subchondral sclerozis and sitokines like IGF-1 and TGF-B are assumed to be the risk factors for $\mathrm{OA}$, though the relationship with the BMD still remains partly undefined (19). In our study it was found that later stages of OA was positively correlated with higher $B M D$, supporting the Chingford and Framingham studies $(4,16)$. The hypothesis of negative correlation between OA and osteoporosis was corroborated.

Another study revealed that later stages of knee OA was together with lower proximal femoral BMD scores ipsilaterally because of not using the extremity to avoid pain. The lomber BMD was not influenced by this result (20). There is positive and strong evidence that osteophytosis may be with or cause higher BMD (21). High BMI (obesity) is a very important risk factor for OA while it is a relative protective factor for osteoporosis $(22,23)$. Bone mineral loss slows in the patients with excessive fat tissue producing estrogen which is responsible for the release of IGF-1 and TGF-B from the osteblasts and by mitogenic response to leptin and hyperinsulinemia $(24,25)$. Obesity may cause degenerative processes like OA which may be also related to high adipokine levels and inflammation (26). Because it is also a disability determinant and pain generator by mechanic and metabolic reasons, Osteoarthritis Research Society International recommend to get weight loss by at least $5 \%$ in 20 weeks time (27).

In the literature, there is a moderate-strong correlation between reliability of MRI and USG for evaluation of the FCT. Middle

Table 2. K-L staging of the right and left knees and their relation with the BMD T-scores

\begin{tabular}{|l|l|l|l|l|}
\hline & $\begin{array}{l}\text { FN (T-score) } \\
\text { Mean } \pm \text { SD }\end{array}$ & $\begin{array}{l}\text { LT (T-score) } \\
\text { Mean } \pm \text { SD }\end{array}$ & $\begin{array}{l}\text { FT (T-score) } \\
\text { Mean } \pm \text { SD }\end{array}$ & $\begin{array}{l}\text { BMI }\left(\mathbf{k g} / \mathbf{m}^{2}\right) \\
\text { Mean } \pm \text { SD }\end{array}$ \\
\hline Right knee K-L stage 1 $(n=34)$ & $-1.40 \pm 1.06$ & $-2.04 \pm 1.10$ & $-0.87 \pm 1.10$ & $27.79 \pm 17.41$ \\
\hline Right knee K-L stage 2 $(n=50)$ & $-1.50 \pm 0.94$ & $-2.03 \pm 0.94$ & $-1.03 \pm 0.95$ & $29.29 \pm 18.45$ \\
\hline Right knee K-L stage 3 $(n=34)$ & $-0.80 \pm 1.47$ & $-1.22 \pm 1.39$ & $-0.48 \pm 1.11$ & $31.92 \pm 20.72$ \\
\hline $\mathbf{p}$ & 0.015 & 0.003 & 0.066 & 0.000 \\
\hline Left knee K-L stage 1 $(n=38)$ & $-1.47 \pm 1.17$ & $-2.5(-3.8-0.1)$ & $-0.93 \pm 1.13$ & $27.75 \pm 18.41$ \\
\hline Left knee K-L stage 2 $(n=49)$ & $-1.43 \pm 0.80$ & $-2.1(-3.1-0.9)$ & $-0.94 \pm 0.87$ & $29.28 \pm 17.61$ \\
\hline Left knee K-L stage 3 $(n=31)$ & $-0.84 \pm 1.45$ & $-1.3(-4.5-2.0)$ & $0.54 \pm 1.12$ & $31.91 \pm 22.30$ \\
\hline $\mathbf{p}$ & 0.045 & 0.012 & 0.206 & 0.001 \\
\hline K-L: Kellgren Lawrence, FN: Femur neck, LT: Lomber total, FT: Femur total, SD: Standard deviation, BMI: Body mass index & \\
\hline
\end{tabular}

Table 3. Correlation of FCT with demographic variables, quality of life and disability scores

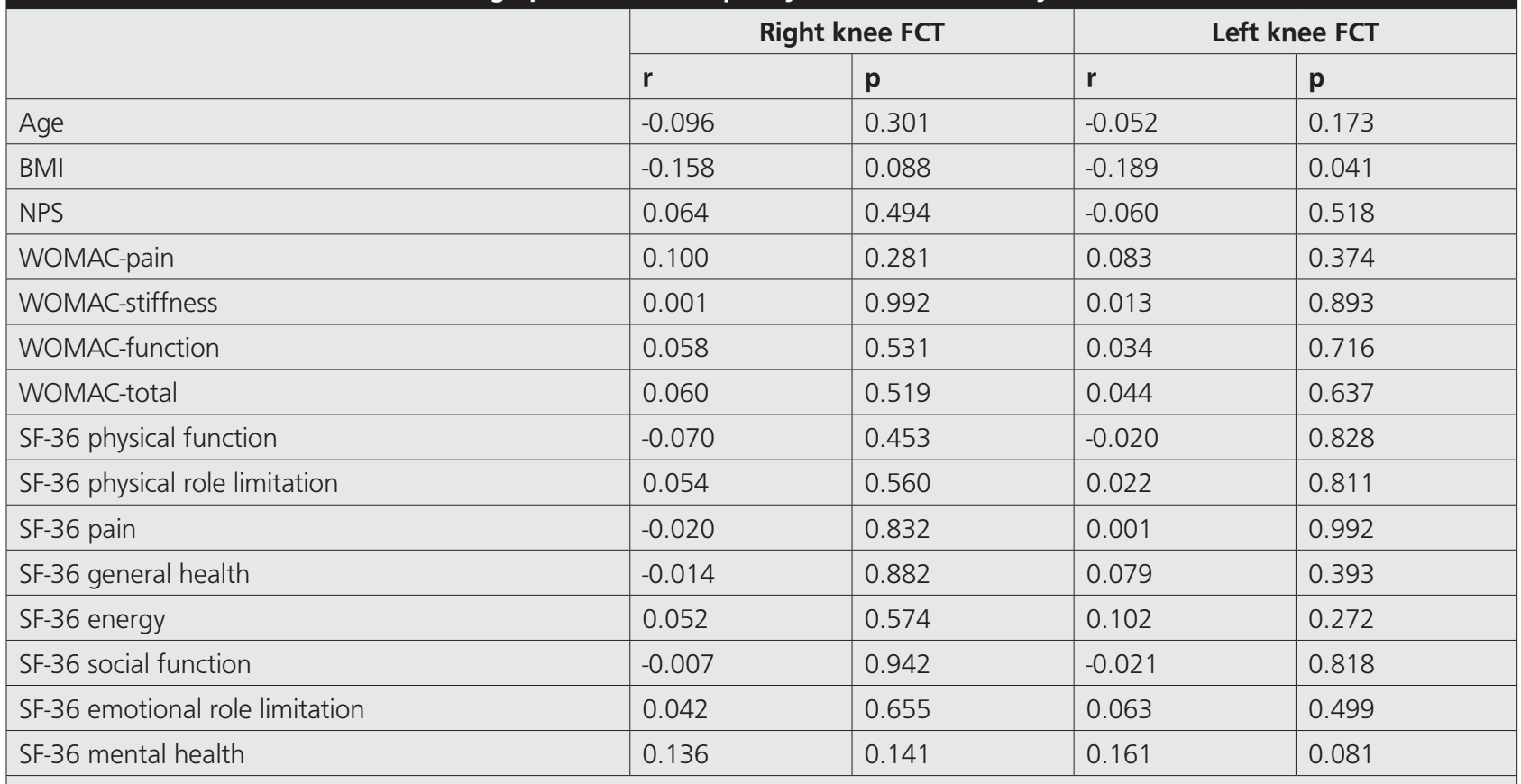

FCT: Femoral cartilage thickness, SF-36: Short Form-36, WOMAC: Western Ontario and McMaster University Osteoarthritis index, BMI: Body mass index, $\mathrm{r}$ : Correlation coefficient, NPS: Numeric pain scale 
intercondyller notch seems to be the best anatomic place to measure $(28,29)$. In this study USG is preferred for evaluation because of its reliability, repeatibility and cheapness.

Dequeker et al. (24) claimed that excessively high subchondral bone density may cause progressive chondrocyte disfunction in the early stages of cartilage destruction. Increase of the peak mechanical stress at the cartilage of the weight bearing bone with high BMD plays the major role in OA (30). Some other studies have contradictory results in which low BMD means high bone remodelization, with similar accelerating effect on cartilage turnover and inadequate restoration $(3,31,32)$.

These literature knowledge reveals the conflicting and complex relationship between these 2 diseases with several contributing factors in the intersecting etiology such as metabolic, mechanical, genetic or endocrinologic. Low BMI is a risk factor for osteoporosis while high BMI is a risk factor for OA progression as also explained in our study. There was not an association between ultrasonographic FCT and osteoporosis in our study similar to another submitted study by Çarlı et al. (33).

\section{Study Limitations}

Limitations of the study were; patients having antiresorptive medication were not excluded, and the sample size is relatively low according to these type of observational studies. Bisphosphonates are antiresorptive agents used for treating osteoporosis and have inhibition effect on osteoklasts. Because it's thought that antiresorptive medication decreases both bone and cartilage turnover, it's reasonable to think that supression of the subchondral bone remodeling may cause a common advantage by delaying the subchondral bone sclerozis and osteophyte formation in OA and may have changed the long term clinic progress (34-39).

\section{Conclusion}

Later stages of OA may be positively correlated with high BMD but this is still a question in dispute that if it is a cause or a result? As a conclusion, high BMI may lead to OA progression and disability but has protective effect for osteoporosis. There is also a reason to think that, DXA BMD measurements may be false negative in later stages of OA, because of osteophytosis and subchondral bone sclerozis. There is a need for studies evaluating ultrasonographic FCT with larger sample sizes and may be combined with laboratory detection of cartilage destruction products and its relationship with osteoporosis medication.

\section{Ethics}

Ethics Committee Approval: Uludağ University Clinical Research Ethics Committee approval was obtained for the study with the number of 2016-7/13 (date: 12.04.2016).

Informed Consent: All subjects who met the study criteria were informed of the nature of the study and a written consent was obtained.

Peer-review: Externally and internally peer-reviewed.

\section{Authorship Contributions}

Surgical and Medical Practices: G.A.Ö., Concept: A.A., G.A.Ö., Design: A.A., G.A.Ö., Data Collection or Processing: A.A., G.A.Ö., Analysis or Interpretation: A.A., G.A.Ö., Literature Search: A.A., G.A.Ö., Writing: A.A.

Conflict of Interest: No conflict of interest was declared by the authors.

Financial Disclosure: The authors declared that this study has received no financial support.

\section{References}

1. Man GS, Mologhianu G. Osteoarthritis pathogenesis - a complex process that involves the entire joint. J Med Life 2014;7:37-41.

2. Kanis JA, Glüer CC. An update on the diagnosis and assessment of osteoporosis with densitometry. Committee of Scientific Advisors, International Osteoporosis Foundation. Osteoporos Int 2000:11:192-202

3. Bellido M, Lugo L, Roman-Blas JA, Castañeda S, Caeiro JR, Dapia $S$, et al. Subchondral bone microstructural damage by increased remodelling aggravates experimental osteoarthritis preceded by osteoporosis. Arthritis Res Ther 2010;12:R152.

4. Hannan MT, Anderson JJ, Zhang Y, Levy D, Felson DT. Bone mineral density and knee osteoarthritis in elderly men and women. The Framingham Study. Arthritis Rheum 1993;36:1671-80.

5. Burger $H$, van Daele $P L$, Odding $E$, Valkenburg HA, Hofman A, Grobbee $D E$, et al. Association of radiographically evident osteoarthritis with higher bone mineral density and increased bone loss with age. The Rotterdam Study. Arthritis Rheum 1996;39:816.

6. Im Gl, Kim MK. The relationship between osteoarthritis and osteoporosis. J Bone Miner Metab 2014;32:101-9.

7. Geusens PP, van den Bergh JP. Osteoporosis and osteoarthritis: shared mechanisms and epidemiology. Curr Opin Rheumatol 2016;28:97-103.

8. Ferrari AG, Cossiolo DC, Silva MKP, da Silva DC. Osteoartritephysiopathology: reviewarticle. MOJ OrthopRheumatol 2018;10:307-9.

9. Altman R, Asch E, Bloch D, Bole G, Borenstein D, Brandt K, et al. Development of criteria for the classification and reporting of osteoarthritis. Classification of osteoarthritis of the knee. Diagnostic and Therapeutic Criteria Committee of the American Rheumatism Association. Arthritis Rheum 1986;29:1039-49.

10. Kellgren JH, Lawrence JS. Radiological assessment of osteoarthrosis. Ann Rheum Dis 1957; 16:494-502.

11. Ferraz MB, Quaresma MR, Aquino LR, Atra E, Tugwell P, Goldsmith $\mathrm{CH}$. Reliability of pain scales in the assessment of literate and illiterate patients with rheumatoid arthritis. I Rheumatol 1990;17:1022-4.

12. Tüzün EH, Eker L, Aytar A, Daşkapan A, Bayramoğlu M. Acceptability, reliability, validity and responsiveness of the Turkish version of WOMAC osteoarthritis index. Osteoarthritis Cartilage 2005; 13:28-33.

13. Lins L, Carvalho FM. SF-36 total score as a single measure of health-related quality of life: Scoping review. SAGE Open Med 2016;4:2050312116671725

14. Çelik D, Çoban Ö. Short Form Health Survey version-2.0 Turkish (SF-36V2) is an efficient outcome parameter in musculoskeletal research. Acta Orthop Traumatol Turc 2016;50:558-61.

15. Dasher LG, Newton CD, Lenchik L. Dual X-ray absorptiometry in today's clinical practice. Radiol Clin North Am 2010;48:541-60.

16. Hart DJ, Mootoosamy I, Doyle DV, Spector TD. The relationship between osteoarthritis and osteoporosis in the general population: the Chingford Study. Ann Rheum Dis 1994;53:158-62.

17. Nevitt MC, Lane NE, Scott JC, Hochberg MC, Pressman AR, Genant $H K$, et al. Radiographic osteoarthritis of the hip and bone mineral 
density. The Study of Osteoporotic Fractures Research Group. Arthritis Rheum 1995;38:907-16.

18. Arden NK, Nevitt MC, Lane NE, Gore LR, Hochberg MC, Scott $J C$, et al. Osteoarthritis and risk of falls, rates of bone loss, and osteoporotic fractures. Study of Osteoporotic Fractures Research Group. Arthritis Rheum 1999;42:1378-85.

19. Deng ZH, Zeng C, Li YS, Yang T, Li H, Wei J, et al. Relation between phalangeal bone mineral density and radiographic knee osteoarthritis: a cross-sectional study. BMC Musculoskelet Disord 2016;17:71.

20. Im Gl, Kwon OJ, Kim CH. The relationship between osteoarthritis of the knee and bone mineral density of proximal femur: a crosssectional study from a Korean population in women. Clin Orthop Surg 2014;6:420-5.

21. Hardcastle SA, Dieppe $P$, Gregson $C L$, Arden NK, Spector TD, Hart DJ, et al. Osteophytes, enthesophytes, and high bone mass: a bone-forming triad with potential relevance in osteoarthritis. Arthritis Rheumatol 2014;66:2429-39.

22. Rexhepi S, Bahtiri E, Rexhepi M, Sahatciu-Meka V, Rexhepi B. Association of Body Weight and Body Mass Index with Bone Mineral Density in Women and Men from Kosovo. Mater Sociomed 2015;27:259-62.

23. Tariq $S$, Tariq $S$, Lone KP. Relationship of anthropometric measures with bone mineral density in postmenopausal non-osteoporotic osteopenic and osteoporotic women. J Pak Med Assoc 2017;67:590-4.

24. Dequeker J, Johnell O, Dilsen G, Gennari C, Lopes Vaz AA, Lyritis $\mathrm{G}$, et al. Osteoarthritis protects against femoral neck fracture: The MEDOS study experience. Bone 1993;14(Suppl 1):51-6.

25. Considine RV, Sinha MK, Heiman ML, Kriauciunas A, Stephens TW, Nyce MR, et al. Serum immunoreactive-leptin concentrations in normal-weight and obese humans. N Engl J Med 1996;334:292-5.

26. Poonpet T, Honsawek S. Adipokines: Biomarkers for osteoarthritis? World J Orthop 2014;5:319-27.

27. McAlindon TE, Bannuru RR, Sullivan MC, Arden NK, Berenbaum F, Bierma-Zeinstra SM, et al. OARSI guidelines for the non-surgical management of knee osteoarthritis. Osteoarthritis Cartilage 2014;:22:363-88

28. Schmitz RJ, Wang HM, Polprasert DR, Kraft RA, Pietrosimone BG. Evaluation of knee cartilage thickness: A comparison between ultrasound and magnetic resonance imaging methods. Knee 2017;24:217-23.
29. Pradsgaard DØ, Fiirgaard B, Spannow AH, Heuck C, Herlin T. Cartilage thickness of the knee joint in juvenile idiopathic arthritis: comparative assessment by ultrasonography and magnetic resonance imaging. J Rheumatol 2015;42:534-40.

30. Sambrook $P$, Naganathan $V$. What is the relationship between osteoarthritis and osteoporosis? Baillieres Clin Rheumatol 1997;11:695-710

31. Lo GH, Hunter DJ, Zhang Y, McLennan CE, Lavalley MP, Kiel DP, et al. Bone marrow lesions in the knee are associated with increased local bone density. Arthritis Rheum 2005;52:2814-21.

32. Cao $Y$, Stannus OP, Aitken D, Cicuttini F, Antony B, Jones $G$, et al. Cross-sectional and longitudinal associations between systemic, subchondral bone mineral density and knee cartilage thickness in older adults with or without radiographic osteoarthritis. Ann Rheum Dis 2014;73:2003-9.

33. Çarlı AB, Akarsu S, Tekin L, Sağlam M, Kıralp MZ, Özçakar L. Ultrasonographic assessment of the femoral cartilage in osteoarthritis patients with and without osteoporosis. Aging Clin Exp Res 2014;26:411-5

34. Saag KG. Bisphosphonates for osteoarthritis prevention: "Holy Grail" or not? Ann Rheum Dis 2008;67:1358-9.

35. Carbone LD, Nevitt MC, Wildy K, Barrow KD, Harris F, Felson D, et al. The relationship of antiresorptive drug use to structural findings and symptoms of knee osteoarthritis. Arthritis Rheum 2004:50:3516-25

36. Lampropoulou-Adamidou K, Dontas I, Stathopoulos IP, Khaldi L, Lelovas P, Vlamis J, et al. Chondroprotective effect of high-dose zoledronic acid: An experimental study in a rabbit model of osteoarthritis. J Orthop Res 2014;32:1646-51.

37. Shirai T, Kobayashi M, Nishitani K, Satake T, Kuroki H, Nakagawa Y, et al. Chondroprotective effect of alendronate in a rabbit model of osteoarthritis. J Orthop Res 2011;29:1572-7.

38. Lehmann HJ, Mouritzen U, Christgau S, Cloos PA, Christiansen C. Effect of bisphosphonates on cartilage turnover assessed with a newly developed assay for collagen type II degradation products. Ann Rheum Dis 2002;61:530-3.

39. Fujita $T$, Ohue M, Fujii $Y$, Miyauchi A, Takagi $Y$. Analgesic and chondroprotective effects of risedronate in osteoarthritis assessed by electroalgometry and measurement of collagen type II fragments in urine. J Int Med Res 2008;36:932-41. 